helping me revise the paper. The Norfolk and Norwich Bicentenary Trust kindly provided a grant.

\section{References}

1. Hand C. Adherence and asthma. In: Myers L B and Midence K, eds. Adherence to treatment in medical conditions. Amsterdam, Harwood Academic Press, 1998; 383-421.

2. Britten N. Patients' ideas about medicines: a qualitative study in a general practice population. $\mathrm{Br}$ J Gen Pract 1994; 44: 465-8.

3. Conner M, Norman P, eds. Predicting health behaviour. Buckingham, Open University Press, 1996.

4. Hibbert D. Professional and user perspectives on asthma care and inhaler therapy [ $\mathrm{PhD}$ thesis] Manchester, Manchester University Press, 1997. 5. Kibble K T. A qualitative study of patients attitudes to their asthma and its treatments. Asthma in Gen Pract 1997; 5(2): 25-6.

6. Hall J A, Roter D L, Katz N R. Meta-analysis of correlates of provider behavior in medical encounters. Medical Care 1988; 26: 657-75.

7. Hand C H, Bradley C. Health beliefs of adults with asthma: toward an understanding of the difference between symptomatic and preventive use of inhaler treatment. J of Asthma 1996; 33: 331-8.

8. Ley P. Satisfaction, compliance and

communication. Br J Clin Psychol 1982; 21: 241-54. 9. Barritt PW, Staples E B. Measuring success in asthma care: a repeat audit. Br J Gen Pract 1991; 41: 232-6.

10. Osman L M, Russell I T, Friend J A R et al. Predicting patient attitudes to asthma medication. Thorax 1993; 48: 827-30.

11. National Asthma Campaign. The impact of asthma. London, NAC, 1996.
Table 3: Correlations between beclomethasone dipropionate and salbutamol factors (Spearman's rho) with two-tailed significance levels

\begin{tabular}{|c|c|c|c|c|c|c|c|c|c|c|c|c|c|}
\hline & S1 & S2 & S3 & S4 & S5 & S6 & S7 & B1 & B2 & B3 & B4 & B5 & B6 \\
\hline S1 & 1.000 & & & & & & & & & & & & \\
\hline S2 & 0.071 & 1.000 & & & & & & & & & & & \\
\hline S3 & 0.033 & 0.025 & 1.000 & & & & & & & & & & \\
\hline S4 & 0.033 & -0.113 & 0.083 & 1.000 & & & & & & & & & \\
\hline S5 & 0.087 & 0.045 & 0.022 & -0.060 & 1.000 & & & & & & & & \\
\hline S6 & 0.022 & -0.004 & 0.048 & 0.031 & 0.019 & 1.000 & & & & & & & \\
\hline S7 & -0.43 & -0.13 & 0.013 & 0.002 & -0.059 & 0.067 & 1.000 & & & & & & \\
\hline B1 & $-0.652^{\star *}$ & -0.47 & 0.123 & -0.017 & -0.188 & -0.264 & 0.029 & 1.000 & & & & & \\
\hline B2 & 0.019 & 0.182 & 0.163 & 0.190 & -0.057 & -0.016 & 0.107 & 0.030 & 1.000 & & & & \\
\hline B3 & 0.085 & $0.324^{*}$ & -0.127 & 0.168 & -0.076 & 0.096 & -0.020 & 0.144 & -0.055 & 1.000 & & & \\
\hline B4 & 0.067 & 0.061 & 0.164 & -0.094 & 0.141 & -0.294 & -0.163 & 0.062 & 0.060 & 0.073 & 1.000 & & \\
\hline B5 & 0.122 & 0.211 & $-0.379^{*}$ & -0.168 & $0.537^{\star \star}$ & 0.072 & 0.245 & -0.110 & 0.107 & -0.084 & -0.232 & 1.000 & \\
\hline B6 & 0.088 & 0.213 & -0.244 & $-0.489^{\star \star}$ & ${ }^{*}-0.131$ & 0.161 & -0.083 & -0.083 & 0.105 & -0.048 & -0.040 & 0.094 & 1.00 \\
\hline & $\begin{array}{l}0.001 \\
0.05\end{array}$ & & & & & & & & & & & & \\
\hline
\end{tabular}

\section{Summary of statistical terms}

- Spearman's correlation co-efficient (rho): a measure of association between two variables that are not normally distributed (non-parametric test)

- Cronbach's alpha: a measure of internal reliability or consistency of a multiple-item scale that relies upon the associations of each item with each other (inter-item correlation).

- Factor analysis: a complex statistical technique used to identify a relatively small number of factors that can be used to represent relationships among sets of many interrelated variables. It is usually done in four steps:

- Correlation: variables that do not appear related to other variables are identified.

- Factor extraction: the number of factors needed to represent the data is determined.

- Rotation: the factors are transformed to make them more interpretable.

- Factor scoring: scores for each factor are computed for each case.

\title{
Concerns and misconceptions regarding steroid therapy in asthma: findings and impact of a public meeting
}

\author{
D Price, J Hobbs, S Watkins, M Duerden and H Darby
}

\section{SUMMARY}

Anxiety concerning long-term steroid therapy may be translated into non-compliance with prescribed asthma treatment; this was addressed at a public meeting. Questionnaire responses indicated an immediate, positive impact on participants' attitudes to, and misconceptions of, anti-asthma steroid therapy.

\section{INTRODUCTION}

Patient non-compliance is one factor limiting the efficacy of inhaled steroids in asthma management. ${ }^{1}$ Whilst many factors can contribute to patients' nonadherence to therapy, one key element is anxiety about steroid side-effects. ${ }^{2}$ Media reports constantly fuel fears and patients often present with 'scare stories'. Following one particular television programme some patients in a Norwich practice reduced, and others even suspended, steroid therapy.
12. Tabachnick B G, Fidell L S. Using multivariate statistics (3rd edition). New York, HarperCollins, 1996. 
Table 1: Changes in patients' and parents' response to open questions regarding inhaled steroid benefits and side-effects before and after the meeting

\begin{tabular}{|c|c|c|c|c|c|}
\hline $\begin{array}{l}\text { Statements from } \\
\text { patients regarding } \\
\text { inhaled steroids }\end{array}$ & Group & $\begin{array}{l}\text { Pre-meeting } \\
\text { Proportion (numb }\end{array}$ & $\begin{array}{l}\text { Post-meeting } \\
\text { ber responding) }\end{array}$ & Difference & $\begin{array}{l}\text { Yates corrected } \\
\chi^{2}\left(^{*}=p<0.05\right)\end{array}$ \\
\hline $\begin{array}{l}\text { They help prevent } \\
\text { asthma attacks. }\end{array}$ & $\begin{array}{l}\text { Patients } \\
\text { Parents }\end{array}$ & $\begin{array}{l}45 \%(n=38) \\
46 \%(n=35)\end{array}$ & $\begin{array}{l}64 \%(n=25) \\
79 \%(n=24)\end{array}$ & $\begin{array}{l}19 \% \\
33 \%\end{array}$ & $\begin{array}{l}p=0.215 \\
p=0.022^{*}\end{array}$ \\
\hline $\begin{array}{l}\text { They have less side- } \\
\text { effects than oral } \\
\text { steroids. }\end{array}$ & $\begin{array}{l}\text { Patients } \\
\text { Parents }\end{array}$ & $\begin{array}{l}3 \%(n=38) \\
9 \%(n=35)\end{array}$ & $\begin{array}{l}32 \%(n=25) \\
37 \%(n=24)\end{array}$ & $\begin{array}{l}29 \% \\
28 \%\end{array}$ & $\begin{array}{l}p=0.004^{*} \\
p=0.018^{*}\end{array}$ \\
\hline $\begin{array}{l}\text { They have no or } \\
\text { negligible side- } \\
\text { effects. }\end{array}$ & $\begin{array}{l}\text { Patients } \\
\text { Parents }\end{array}$ & $\begin{array}{r}8 \%(n=38) \\
17 \%(n=35)\end{array}$ & $\begin{array}{l}35 \%(n=25) \\
53 \%(n=24)\end{array}$ & $\begin{array}{l}27 \% \\
36 \%\end{array}$ & $\begin{array}{l}p=0.016^{\star} \\
p=0.007^{\star}\end{array}$ \\
\hline
\end{tabular}

able 2: Changes in reported median levels of concerns amongst the different groups attending the meeting (scores ranged from $0=$ not concerned to $6=$ very concerned)

\section{David Price}

General Practitioner and

Honorary Senior Lecturer

\section{Helen Darby}

Medical Researcher

Thorpewood Surgery, Woodside Road, Thorpe, Norwich NR7 OEF, UK.

\section{Jane Hobbs}

Paediatric Asthma Liaison Sister

Royal Alexandra Hospital for Sick Children,

Brighton,

Sussex BN1 3JN, UK.

\section{Simon Watkin}

Consultant Physician

Department of Respiratory Medicine, Norfolk \&

Norwich Hospital,

Norwich NR1 3SR, UK.

\section{Martin Duerden}

Joint Medical Director

National Prescribing Centre, 70 Pembroke Place, Liverpool L69 3GF, UK.

Correspondence to: Dr D B Price

General Practitioner

Manor House, 12

Yarmouth Road,

Thorpewood St Andrew,

Norwich NR7 OEF, UK.

Date received: 18/09/98

Date accepted: 10/11/98

Asthma in Gen Pract 1998 6(3): 43-44.

$\begin{array}{llll}\text { Group } & \begin{array}{l}\text { Pre-meeting } \\ \text { Median score } \\ \text { (IQR), } \mathrm{n}\end{array} & \begin{array}{l}\text { Post-meeting } \\ \text { Median score } \\ \text { (IQR), } \mathrm{n}\end{array} & \begin{array}{l}\text { Mann- } \\ \text { Whitney-U } \\ \text { Test }\end{array} \\ \text { Patients } & 3 \quad(2 \text { to } 3), 52 & 2(2 \text { to } 2), 48 & \mathrm{p}<0.01 \\ \text { Parents } & 4 \quad(3 \text { to } 6), 49 & 2(1.5 \text { to } 2), 33 & \mathrm{p}<0.01 \\ \text { Others } & 3.5(2 \text { to } 5), 22 & 1(1 \text { to } 2), 15 & \mathrm{p}<0.05\end{array}$

completed a questionnaire on behalf of both parents regarding their child or children; children under the age of 12 did not complete questionnaires.

Invited speakers gave a series of short talks covering different aspects of asthma. A question and answer session incorporated input from the questionnaires collated during the meeting. This promoted the airing of concerns that might otherwise not have been raised, through personal embarrassment. The initial impact of the meeting was assessed using a close of meeting' questionnaire based on the questionnaire used at the start of the meeting. Free text fears and perceived benefits were compared using Yates corrected $\chi^{2}$ tests (SPSS - unpaired data as not all attendees answered all questions). The level of concern regarding inhaled steroids on a scale of nought to six was compared using the Mann-Whitney $\mathrm{U}$ test.

\section{RESULTS}

Approximately 200 people attended - including patients, parents and families, pharmacists, practice nurses, teachers and doctors. One hundred and twenty three questionnaires were completed by patients $(n=52)$, parents $(n=49)$ and others $(n=22)$. Not all respondents answered all the questions; particularly the open questions regarding benefits and side-effects of inhaled steroids.

\section{Major findings}

- Eighty two per cent of patients disliked taking oral steroids; $12 \%$ stated that they refused to take them.

- Forty four per cent of patients disliked using inhalers in public; three per cent stated that they refused to do so.

- Most frequently cited concerns were weight gain associated with oral steroid therapy (58\% patients, $33 \%$ parents) and local oral side-effects from inhaled steroids (54\% patients, $27 \%$ parents).

- A major fear was that inhaled steroids caused growth retardation (30\% parents).
- Common misconceptions were that inhaled steroid use caused weight gain (19\% patients, $10 \%$ parents) and dependency (12\% patients).

- Patients $(31 \%)$ and parents $(10 \%)$ confused $\beta_{2}$-agonist effects (tremor, tachycardia) with steroid effects.

- The GP was the main information source for both patients and parents, with media the second most cited source (equal second for patients, alongside their hospital doctor).

- Media reports worried parents $(71 \%)$ more than patients $(39 \%)\left(\chi^{2}(\mathrm{p}<0.001)\right)$. Thirty nine per cent of others completing the questionnaire (the group which included health professionals) had also been influenced by the media.

\section{Impact of the meeting}

The major immediate impact of the meeting regarding attitudes to inhaled steroids found in response to open questions regarding benefits and side-effects of inhaled steroids are summarised in Table 1. Impact in terms of overall levels of concern is shown in Table 2

\section{DISCUSSION}

The questionnaires completed at the meeting revealed two widespread misconceptions amongst respondents regarding inhaled steroid therapy: weight gain and the attribution of $\beta_{2}$-agonist side-effects to the use of inhaled steroids. Patients with asthma (and/or their parents) who attended the meeting (and completed questionnaires) may be considered to have stronger reservations regarding steroid therapy than the asthmatic population as a whole. However, it is possible that the same concerns and misconceptions exist in the wider population. We re-emphasise the importance of discovering patients' own attitudes and concerns when commencing therapy, rather than using fixed education for all patients. ${ }^{4}$

The public format allowed patients' families and friends (known to have a strong and positive influence on adherence to treatment) ${ }^{5}$ to participate and promoted patient (and doctor) interaction, and 'safety in numbers' may well have prompted a greater airing of individual anxieties. The close of meeting questionnaire responses indicated an immediate positive impact on concerns and misconceptions. We cannot speculate whether there was a long-term impact from the meeting in terms of attitudinal change. It would be useful in future to incorporate some long-term assessments of patients' attitudes and adherence to asthma therapy in a such a study.

\section{ACKNOWLEDGEMENTS}

The local Health Authority met costs incurred in holding the meeting

\section{References}

1. Osman L M, Russell I T, Friend J A R et al. Predicting patient attitudes to asthma medication. Thorax 1993; 48: 827-30. 2. Price D. Steroid phobia. Resp Dis Pract 1994; 11(3): 10-3. 3. Wilson S R, Scamagas P, German D F et al. A controlled trial of two forms of self-management education for adults with asthma. Am J Med 1993; 94: 564-76.

4. Ley P. Selecting the Content of Communications. Communicating With Patients. Improving Communication, Satisfaction and Compliance. Psychology \& Medicine Series 1988: 141-56. 5. Taggart V S. Implementation of the guidelines: a patient's perspective. Eur Respir Rev 1995; 5(26): 112-5. 